\title{
Message From THE INCOMING Editors
}

We are deeply honored to serve the profession as editors of AJS Review and humbled by the confidence the AJS Board has reposed in us. We would like publicly to thank our predecessors, Carol Bakhos and Adam Shear. Their superb stewardship of the journal is evident in the high-quality scholarship published in this issue, all of which they selected and guided through peer review and publication. We gained a deep appreciation of their uncompromising commitment to excellence as we shadowed their activities over the last few months. Their patient responses to our questions, and their advice and encouragement to us as we made the transition from observers to editors, is greatly appreciated.

We would also like to thank outgoing book review editor Jay Geller for his dedicated service, and book review editors Francesca Bregoli and Joel S. Kaminsky. We also welcome incoming book review editor Eliyana Adler. We look forward to working with them all. These dedicated colleagues ensure the publication of a lively and diverse book review section that enriches scholarship by bringing books relevant to Jewish studies to the attention of AJS Review readers.

We are grateful to Noam Pianko, president of the AJS, and to Warren Hoffman, the executive director, for their leadership of the AJS and support of the journal. Our editorial transition was greatly eased by the indefatigable managing editor Aviva Arad, whose attention to detail and patient mentoring has made us feel at home in the editors' role. We would also like to express our appreciation to the superb editorial and production team at Cambridge University Press.

AJS Review is part of a larger ecosystem that supports it and enables it to thrive. You, our colleagues and readers of the journal, are a critical component of that ecosystem. We invite you to partner with us in maintaining $A J S$ Review's preeminent status in the profession by sending us your best work and encouraging colleagues to do so. This is an exciting time in Jewish studies. Established fields of study are being challenged and enriched by new methods, and new subfields are emerging. The public face of scholarship in some cases is impacting the shape and focus of the field. Possibilities for interdisciplinary work abound. We believe that AJS Review should be the venue in which these scholarly conversations take place. We look forward to working together with you over the next few years to make this happen. 